\title{
Physio Chemical Properties of Pomegranate Varitieas Collected from Peshawar Local Market
}

\author{
Usman ${ }^{1}$, Saleemullah ${ }^{1}$, Hafeezur Rahim ${ }^{2 *}$, Sajjad Ahmad ${ }^{3}$, Zaid Khan ${ }^{3}$, Iftikhar Jan ${ }^{1}$, M Ayoub Khan ${ }^{4}$ and \\ Muhammad Haris ${ }^{2}$ \\ ${ }^{1}$ Department of Agricultural Chemistry, The University of Agriculture Peshawarm, Pakistan
}

${ }^{2}$ Department of Soil and Environmental Sciences, The University of Agriculture Peshawar, Pakistan

${ }^{3}$ Department of Agronomy, The University of Agriculture Peshawar, Pakistan

${ }^{4}$ Department of Plant breeding \& Genetics, The University of Agriculture Peshawar, Pakistan

Submission: December 01, 2017; Published: February 06, 2018

"Corresponding author: Hafeezur Rahim, Department of Soil and Environmental Sciences, The University of Agriculture Peshawar, Pakistan, Email: hafeez.kalpani@aup.edu.pk

\begin{abstract}
The present study was conducted at the Agricultural chemistry Lab in the University of Agriculture Peshawar, Pakistan to evaluate the physico-chemical properties of two pomegranate verities: Bedana and kandahari. The colour, average weight, edible index and waste index of Bedana observed yellowish, $200.00 \mathrm{~g}$, 31.45\% and $65.00 \%$ while of kandahari was dark red, $250.00 \mathrm{~g}$, 35.55\% and $60.55 \%$ respectively. The average total soluble solid (TSS), reducing sugar, acidity, PH, moisture and ash of Bedana showed 150Brix, 7.00\%, 15.68, 2.87, 78.63\% and 0.4\% while of Kandahari 170Brix, $8.20 \%, 11.76,2.22,80.26 \%$ and $0.6 \%$ respectively. The proximate composition of Na and $\mathrm{K}$ were found $100 \mathrm{mg} / \mathrm{g}$ and $80 \mathrm{mg} / \mathrm{g}$ of Bedana while $150 \mathrm{mg} / \mathrm{g}$ and $220 \mathrm{mg} / \mathrm{g}$ of Kandahari. Among different parameters of Bedana and Kandahari, the dark red colour of Kandahari were eyes appealing to consumers, compared to Bedana Varity. With the various nutritional benefits, the fruits could be recommended for commercial exploitation and preparation of different value added products.
\end{abstract}

Keywords : Pomegranate; Quality; Physical properties via chemical properties

\section{Introduction}

Pomegranate (Punica granatum L.) belongs to the Punicacea family. It is an important commercial fruit crop that is extensively cultivated in parts of Asia, North Africa, the Mediterranean and the Middle East [1]. Iran is one of the most important pomegranate producers and exporters in the world, and its total production in 2005 was 670,000 tons [2].

The fruit is a good source of sugars and vitamin $C$ and a fair source of iron and poor in calcium. The juice contains amino acids such as glutamic acid, aspartic acid, tryptophan, methionine, etc. It is rich in phosphorus. The seeds are rich source of lipids, protein, crude fiber and ash, and also contain sugars and pectin. The seeds yield oil which is composed of several fatty acids. The rind contains polyphenols and mineral matter, which is composed of potassium, calcium, iron and copper.

Pomegranate is proved to have high antioxidant activity and good potency for cancer prevention. The edible part of the fruit contains considerable amounts of acids, sugars, vitamins, polysaccharides, polyphenols and important minerals. Great interest has recently been focused on the addition of polyphenols | to foods and biological systems, due to their well-known abilities to scavenge free radicals, i.e. antioxidant power. The generation of free radicals plays an important role in such as atherosclerosis and brain dis-function. Several studies have reported the reduced-risk efficacy of various extracts or pure compounds from the different parts of pomegranate plant against the growth of microbial pathogens. Pomegranate (Punicagranatum Punicaceae) has been known to considerable pharmacological properties with antimicrobial, antiviral, anticancer, potent antioxidant and anti-mutagenic effects and been used in the markets in the preparation of tinctures, juice, cosmetics and therapeutic formulae. Keeping in view the medicinal importance the present study was aimed for its Proximate Composition, Minerals Content, Antibacterial and antifungal Activity Evaluation of Pomegranate (Punica granatum L.) Peels Powder [3].

Fruits are rich in minerals, which are essential for a wide variety of metabolic and physiologic processes in the human body. Among the nutrients found in fruits, minerals represent a class of inorganic substances that is present in all kinds of 
fruits. The human body needs about twenty different minerals in order to function properly [4]. Fruits are the most important source of both are macro and micro-minerals Pellerano et al. [5], which indispensable for the maintenance of life, growth, and reproduction [6]. Mineral and trace element intake in humans is directly related to their food habits and the food content.

Similarly, the acceptability of pomegranate to the consumer and processor depends on a combination of several quality attributes that are related to the physico-chemical properties including size, skin color, sugar content, acidity and flavor. Pomegranate fruit is consumed directly as fresh arils as well as fresh juice [7].

\section{Material and Methods}

This research work was carried out in the laboratory ofthe Department of Agriculture Chemistry, The University of Agriculture Peshawar, Pakistan during 2014.

\section{Collection of fruits}

Pomegranate varieties (Bedana and Kandahari) were purchased from the local market of Peshawar (Board bazar) and brought to the laboratory of the Department of Agriculture Chemistry, The University of Agriculture, Peshawar, Pomegranate verities were carefully sorted and diseased, damaged, bruised, and immature commodities were discarded.

\section{Physical properties of pomegranate fruits}

Two fresh fruits of each variety were individually analyzed for their physical properties. Fresh fruits were weighted on an electric balance (Sartorius). Then fruits colors were noted. After that cut the fruits with stainless steel knife and manually removed seed, peel and measured percent edible portion, percent waste and percent of juice.

\section{Extraction of juice}

The fruits were washed with water and wiped completely. Each sample was then divided in to two equal portions for juice extraction. Two methods of extraction were applied for extracting of pomegranate juice. First method consisted of manually peeling the fruit, separated the seed and extracted the juice by electric juice centrifuge (blending of seeds). In the second method, fruits were cut in two halves and the juice was immediately extracted using a hand operated juice extractor/ mechanical press. The obtained raw juice from each extraction was filter through muslin cloth. The juices were immediately stored at $4^{\circ} \mathrm{C}$ in the dark until analysis.

\section{Chemical properties of pomegranate fruits}

Pomegranate fruits were analyzed for its total soluble solid (TSS) ( $\left.{ }^{\circ} \mathrm{Bx}\right)$, acidity, $\mathrm{pH}$, moisture, ash, sodium and potassium.

\section{Determination of moisture}

Moisture of the sample was determined by the standard method of AOAC (2012) method no 925.45. Moisture was determined by oven dry method.

\section{Determination of ash}

The ash content was determined using official method of analysis AOAC [8] method no 900.02. Ash content of the samples was determined by furnace (vulcane, 3-130) ignition method.

\section{Reducing sugar}

AOAC [8] method no 920.183, as explained by Lane and Eyon, were observing reducing sugar of all the samples.

Filling A: Dissolve $34.65 \mathrm{gm}$ of CuSo 4 in $500 \mathrm{ml}$ distilled water.

Filling B: Dissolve $173 \mathrm{gm}$ sodium potassium tartrate $+50 \mathrm{gm}$ of $\mathrm{NaOH}$ in $500 \mathrm{ml}$ distilled water.

In $100 \mathrm{ml}$ flask ten $\mathrm{ml}$ of pomegranate juice sample were taking and the flask was filled with distilled water and filled the burette with this solution. Then $5 \mathrm{ml}$ of both Fehling A and B with ten $\mathrm{ml}$ of cleaned water were taken in conical flask and then heated the flask up to boiling. Than sample solution of burette were poured drop wise to the boiling solution of filing A and filing $B$ until the colour become brick read. Without stirring of flask 2-3 drop of methylene blue was added as indicator. When the color become blue for a while titration was not completed, then poured the sample solution till the color of the solution remain brick red in this way repeated the experiment three time an mean value was taken.

\section{Calculation}

Fehling $\mathrm{A}(5 \mathrm{ml})+$ Feling $\mathrm{B}(5 \mathrm{ml})=(\mathrm{zml})$ percent sample solution $=.05 \mathrm{gm}$ of reducing sugar $\times 100 \mathrm{ml}$ of 10 percent sample will contain $.05 \times 100 /(\mathrm{z}) \mathrm{ml}$ of sample solution $=(\mathrm{x})$ grams of reducing sugar

$\%$ reducing sugar in sample $=X \times 100 / 10$.

\section{Determination of PH}

The PH was determined by using the standard method of AOAC (2012) method no 2005.02.pH meter (JENWAY 3510) was used for calculating PH.

\section{Determination of Total Soluble Solid (TSS)}

Standard method of AOAC [8] method no 932.14 and 932.12 were used to observe the total soluble solid (TSS). The total was determined by using Atago refracto-meter at room temperature. Distilled water was used to calibrate the instrument. A clean soft lint or tissue paper was used to clean the refracto-meter after each reading. A small amount of pomegranate juice was dropped on to the prism of refracto-meter, in this way all the samples was observed three time and mean value was taken.

\section{Determination of minerals}

The sample of pomegranate varieties was observed for sodium $(\mathrm{Na})$ and potassium $(\mathrm{K})$ by flame photometer.

\section{Determination of $\mathrm{Na}$ and $\mathrm{K}$}

Flame photometer was used to determined sodium and potassium. 


\section{Reagents}

Potassium standard (1000ppm): 1.901gm of $\mathrm{KCl}$ was weighed dissolved in distilled water and then diluted up to one liter.

Sodium standard (1000ppm): 2.54gm of dried $\mathrm{NaCl}$ was weighed, dissolved in distilled water and then diluted up to 1 liter. A series of standard solution: $0.1 \mathrm{ppm}, 1 \mathrm{ppm}, 3 \mathrm{ppm}, 5 \mathrm{ppm}$, $10 \mathrm{ppm}, 15 \mathrm{ppm}, 30 \mathrm{ppm}, 50 \mathrm{ppm}$, for both of the sodium and potassium made from stock solution.

\section{Digestion of samples}

In digestion flask taken $5 \mathrm{ml}$ sample and $10 \mathrm{ml}$ nitric acid. Then it was kept for overnight. Next day was added $4 \mathrm{ml}$ perchloric acid and kept all samples on digestion assembly to evaporate the perchloric acid. When the colour become transparent then removed all sample from digestion assembly and then added distilled volume up to $100 \mathrm{ml}$.all the samples were kept in plastic bottle for furthered analysis.

\section{Assay}

The flame photometer (Barloworld-PFP-7) was started and kept it on for about 30 mints and then calibrated with the $\mathrm{Na}$ standard $(0.1-50 \mathrm{ppm})$. The standard emission reading were used for the preparation of calibrate curve. After the calibration with $\mathrm{Na}$ different dilutions.

Variety Fruit color Weight of Fruit (g), Weight of peel (g), Waste index (\%), Edible index (\%)

Bedana Yellowish 200.0070 .55

60.5531 .4

Kandahari Dark red 250.00 85.88 35.55 65.00 the samples were run on the flame photometer to get their emission reading for $\mathrm{Na}$ in the sample. The same procedure was repeated for $\mathrm{K}$ in the sample. Concentration of $\mathrm{Na}$ and $\mathrm{K}$ in the sample were calculated from their respective calibration curves in the micro gram per gram and then written as ppm.

\section{Determination of acidity}

In a conical flask, $5 \mathrm{ml}$ sample and added $50 \mathrm{ml}$ methylated spirit were taken and gently shacked. The attached an air condenser at the mouth of flask and then heated it on a water bath for half an hour. When the sample has been digested completely and then added a drop of phenolphthalein to it. Titrate it against $0.1 \mathrm{NKOH}$. Noted the amount of $\mathrm{KOH}$ used. The end point was pink color.

Calculation;

$$
\text { Acidity }=\frac{\text { AmountofKOHused } \times N o f K O H \times E q . W t . o f K O H}{\text { wtofsample }}
$$

\section{Results and Discussion}

Table 1: Fruit color, fruit and peel weight (g), waste and edible index of Bedanaand Kandhari.
Table 1 : data on physical characteristics of pomegranate shows that the colour of fruits of Bedana variety was yellowish with pink patches and that of Kandahari verity was dark red. The average weight of fruit of Bedana was $200.00 \mathrm{~g}$ while weight of Kandahari was $250.00 \mathrm{~g}$. The edible portion and waste index in Bedana were $31.40 \%$ and $60.55 \%$ respectively, while in Kandhari these were $65.00 \%$ and $35.55 \%$ respectively. The edible portion was found to be more in Kandhari than in Bedana. The results of present study were in good accordance with results reported by Patil et al. [9].

Table 2 shows the acidity of Bedana and Kandhari juice $15.68 \%$ and $11.76 \%$ respectively. The $\mathrm{pH}$ of juice of Bedana and kandahari fruit was 2.22 and 2.87 respectively. The moisture content of Kandhari $80.26 \%$ was slightly higher than that of Bedana $78.63 \%$. The ash content of Bedana and Kandhari was $0.4 \%$ and $0.6 \%$, respectively.

Table 2: Percent acidity, moisture, ash and $\mathrm{pH}$ of the Bedana and Kandhari.

\begin{tabular}{|c|c|c|c|c|}
\hline Varity & $\mathbf{p H}$ & $\begin{array}{c}\text { Acidity } \\
\mathbf{( \% )}\end{array}$ & $\begin{array}{c}\text { Moisture } \\
\mathbf{( \% )}\end{array}$ & Ash (\%) \\
\hline Bedana & 2.22 & 15.68 & 78.63 & 0.4 \\
\hline
\end{tabular}

Table 3: $\mathrm{Na}$ and $\mathrm{K}(\mathrm{mg} / \mathrm{g})$ content of the Bedana and Kandhari.

\begin{tabular}{|c|c|c|}
\hline Variety & Sodium(Na)Mg/g & Potassium(K)Mg/g \\
\hline Bedana & 100 & 80 \\
\hline Kandahari & 150 & 220 \\
\hline
\end{tabular}

Table 4: Total soluble solids (TSS) in Brix and percent reducing sugar of Bedana and Kandahari.

\begin{tabular}{|c|c|c|}
\hline Variety & TSS(0Brix) & Reducing sugar (\%) \\
\hline Bedana & 15 & 7 \\
\hline Kandahari & 17 & 8.2 \\
\hline
\end{tabular}

Table 3 shows that amount of sodium content found in Bedana (100ppm) was less than that of Kandhari (150ppm). The second graph show that amount of Potassium present in Kandhari was $220 \mathrm{ppm}$ and $80 \mathrm{ppm}$ in Bedana. Similar results were reported by Fadavi et al. [10] for different cultivars of pomegranate.

It is observed from Table 4 that the TSS of juice from Kandahari $\left(17^{\circ}\right.$ Brix) was slightly higher than that of Bedana $\left(15^{\circ}\right.$ Brix).The reducing sugar content of Bedana and Kandhari was 7.00 and $8.20 \%$, respectively [11-22].(Figure 1-4) 


\section{Agricultural Research \& Technology: Open Access Journal}

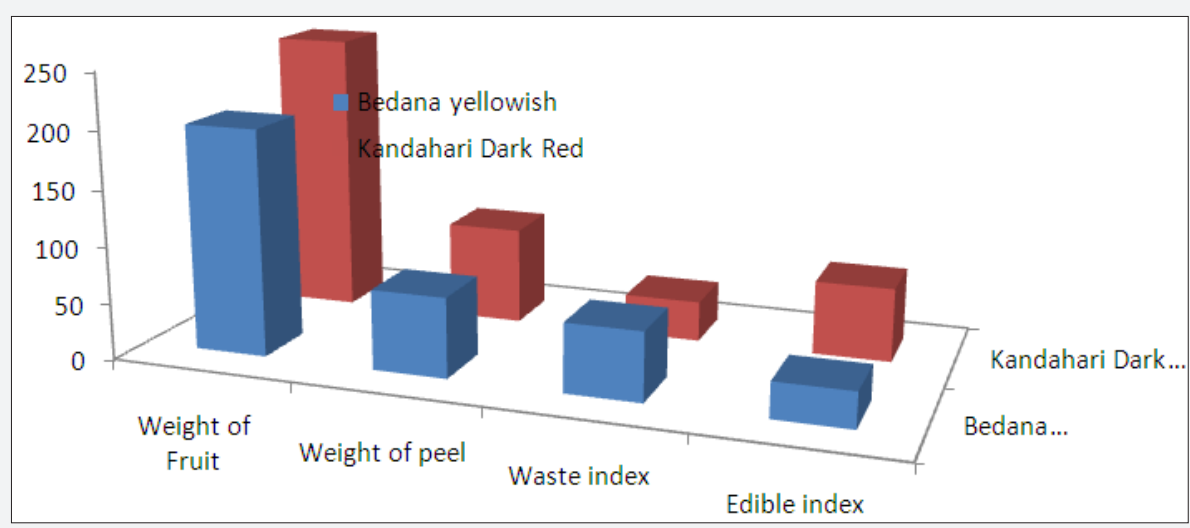

Figure 1: Fruit color, fruit and peel weight (g), waste and edible index of Bedana and Kandhari.

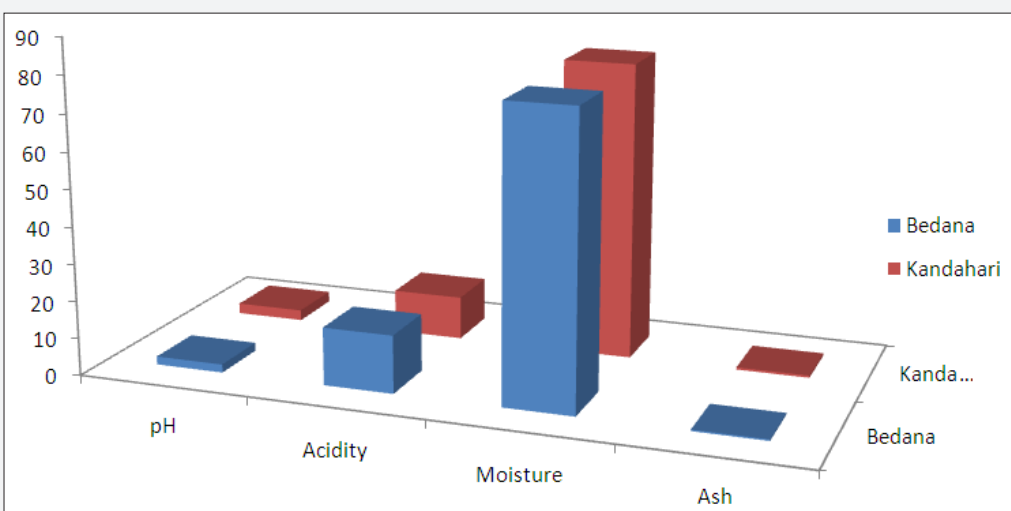

Figure 2 : Percent acidity, moisture, ash and $\mathrm{pH}$ of the Bedana and Kandhari.

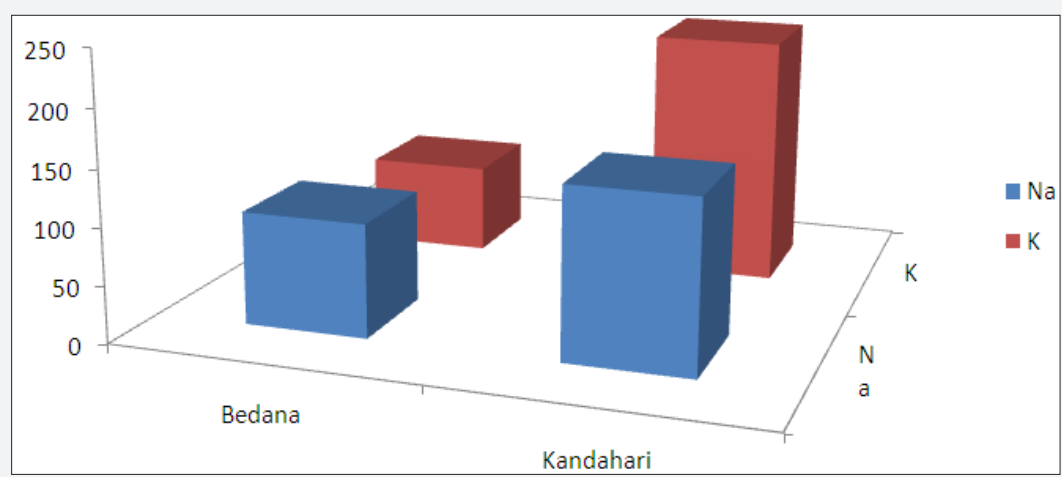

Figure 3 : Na and $\mathrm{K}(\mathrm{mg} / \mathrm{g})$ content of the Bedana and Kandhari.

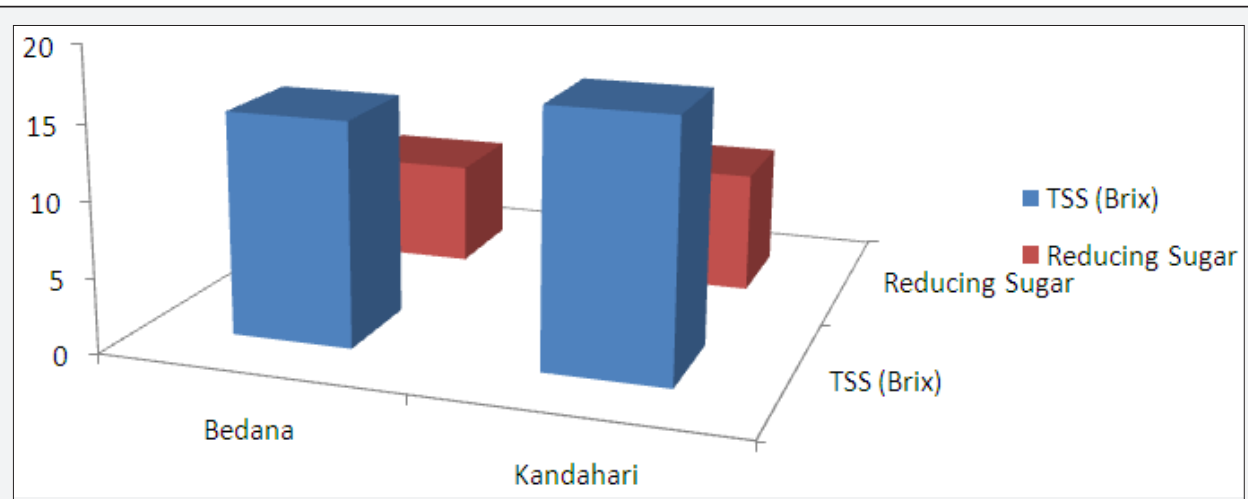

Figure 4 : Total soluble solids (TSS) in Brix and percent reducing sugar of Bedana and Kandahari. 


\section{Conclusion}

Nevertheless, the pomegranate has commercial potential for production of health related food products, but the systematic and organized approach should be followed with other sophisticated methods for retention of other bio-active components, storage life, clinical studies and packaging requirements.

It was concluded that the chemical parameters of fruit determined were TSS, acidity, $\mathrm{pH}$, moisture, ash content, reducing sugar, which were quite similar for both varieties but sodium and potassium content in both verities were quite different. Among different parameters of Bedana and kandahari, the dark red colour of Kandahari were eyes appealing to consumers, compared to Bedana Varity. With the various nutritional benefits, the fruits could be recommended for commercial exploitation and preparation of different value added products.

\section{Acknowledgement}

The Author is very much thankful to the Department of Agricultural Chemistry, The University of Agriculture Peshawar for providing facilities and support during this research work.

\section{References}

1. Sarkhosh A, Zamani Z, Fatahi R, Ebadi A (2006) RAPD markers reveal polymorphism.

2. Anonymous (2005) Statistical Book of Agricultural of Iran. Iranian Statistical Centre, Tehran, Iran.

3. Salaheddin ME, Kader AA (1984) Post-harvest physiology and storage behavior of pomegranate fruits. Sci Hort 24: 287-298.

4. Williams M (2006) Dietary supplements and sports performance: metabolites, constituents, and extracts. J Int Soc Sports Nut 3: 1-5.

5. Pellerano RG, Mazza SS, Marigliano RA, Marchevsky EJ (2008) Multielement analysis of Argentinean lemon juices by instrumental neutronic activation analysis and their classification according to geographical origin. J Agric Food Chem 56: 5222-5225.

6. Alsafwah S, Laguardia SP, Arroyo M, Dockery BK, Bhattacharya SK, et al. (2007) Congestive heart failure is a systemic illness: a role for minerals and micronutrients. Clin Med Res 5(4): 238-243.

7. Al-Said FA, Opara LU, Al-Yahyali RA (2009) Physico-chemical and textural quality attributes of pomegranate cultivars (Punicagranatum L.) grown in the Sultanate of Oman. J Food Eng 90: 129-134.
8. AOAC (2012) Official method of analysis. AOAC international ( $19^{\text {th }}$ edn), Gaithersburg Maryland, USA 2: 20877-22417.

9. Priyanka P, Sayed HM, Joshi AA, Jadhav BA (2013) Comparative evaluation of physico-chemical properties of two varieties of pomogranate fruits-Ganesh and Arakta. Afr J of food sci 7(11): 428430.

10. Fadavi A, Berzegar M, Azizi MH (2006) Determination of fatty acids and total lipid content in seds of 25 pomegranate varieties grown in Iran. J Food Comp Anal 19: 676-680.

11. Among some Iranian pomegranate (Punicagranatum L.) genotypes. Sci Hortic 111: 24-29.

12. Berry SK (2005) Pomegranate: A Miracle Fruit. Review article. Indian Food Packer 189-194.

13. Bose TK, Mitra SK, Sanyal D (2002) Fruits: tropical and subtropical. NayaUdyog, Kolkata, India 2(3): 125-162.

14. Cristosto CH, Mitcham EJ, Kader AA (2000) Pomegranate: recommendations for maintaining postharvest quality. Produce Facts. Postharvest Research and Information Centre, University of California, Davis, USA.

15. Ferial A, Somia H, Abdelatif R, Rahel A, Muhsi SA, et al. (2014) The Physico-Chemical Properties of Pomegranate Juice (Punicagranatum L.) Extracted From Two Egyptian Varieties. World Journal of Dairy \& Food Sciences 9(1): 29-35.

16. Mahan KL, Stump SE (2005) Krause's Food. Nutrition \& Diet Therapy, Saunders, Philadelphia, USA, 12: 13520.

17. Olaniyi A, Opera FUL (2012) Changes in physical properties, chemical and elemental composition and antioxidant capacity of pomegranate (cv. Ruby) fruit at five maturity stage. Scientia Horticulturae 150: 3746.

18. Salah A Al-Maiman, Dilshad A (2002) Changes in physical and chemical properties during pomegranate (Punicagranatum $L$.) fruit maturation. Food Chemistry 76: 437-441.

19. Seyed HM, Rahemi M (2007) Seasonal changes of mineral nutrients and phenolics in pomegranate (Punicagranatum L.) fruit. Scientia Horticulturae 111(2): 120-127.

20. Vahid A, Hemmati K, Sharifani M (2009) Physical and Chemical Properties of Pomegranate (Punicagranatum L.) Fruit in Maturation Stag. American-Eurasian J Agric \& Environ Sci 6(4): 411-416.

21. Vasconcelos LC, Sampaio MC, Sampaio FC, Higino JS (2003) Use of Punicagranatum as an antifungal agent against candidosis associated with denture stomatitis. Mycoses 46(5-6): 192-196.

22. Vidal A, Fallarero A, Pena BR, Medina ME, Gra B, et al. (2003) Studies on the toxicity of Punicagranatum L. (Punicaceae) whole fruit extracts. J Ethnopharmocol 89(2-3): 295-300.

This work is licensed under Creative

Commons Attribution 4.0 License

DOI:10.19080/ARTOAJ.2018.14.555903
Your next submission with Juniper Publishers will reach you the below assets

- Quality Editorial service

- Swift Peer Review

- Reprints availability

- E-prints Service

- Manuscript Podcast for convenient understanding

- Global attainment for your research

- Manuscript accessibility in different formats

( Pdf, E-pub, Full Text, Audio)

- Unceasing customer service

Track the below URL for one-step submission https://juniperpublishers.com/online-submission.php 